\title{
EFEKTIFITAS PENGELOLAAN AIR MINUM UNTUK RUMAH TANGGA
}

\author{
Nurbaiti, Yusmidiarti, Agus Widada
Politeknik Kesehatan Kementerian Kesehatan Bengkulu, Jurusan Kesehatan Lingkungan,
Jl. Indragiri No.3 Padang Harapan Bengkulu
e-mail: nurbaitibeti222@yahoo.com

\begin{abstract}
Abstrak : Water is one of natural resources that has a very important function for human life. Based on research, the coliform bacteria produces etionin substances that can cause cancer and also illness if the amount was excessive in the body. The purpose of this research was to determine the number of bacteria in the water after doing filtration by using a 0.5 micron and 0.1 micron cartridge to the total of coliform bacteria.

Data were analyzed by bivariate analysis using t-test. The results showed that there was no difference to the average number of bacteria that were filtered between the first and the second filtrations. This study was an experimental research design using pre and post-only design.

The results based on laboratory testing showed that there was reduction in the number of coliform bacteria after filtering using a 0.5 micron and 0.1 micron cartridge.

This filtration can be used to reduce the amount of bacteria in the water and if it is added with a complete tool can be used for water treatment.
\end{abstract}

Keywords : water, coliform bacteria, drinking water treatment

\begin{abstract}
Abstrak : Air merupakan salah satu sumber daya alam yang memiliki fungsi sangat penting bagi kehidupan manusia. Berdasarkan penelitian, bakteri coliform ini menghasilkan zat etionin yang dapat menyebabkan kanker selain juga dapat menimbulkan penyakit bila jumlahnya berlebih dalam tubuh. Tujuan penelitian ini untuk mengetahui jumlah bakteri yang ada dalam air sesudah dilakukannya penyaringan dengan menggunakan cartridge berukuran 0,5 mikron dan 0,1 mikron terhadap jumlah bakteri coliform.

Data dianalisis dengan analisis bivariat menggunakan uji t-test. Hasil penelitian menunjukkan rerata jumlah bakteri yang tersaring antara penyaringan satu dengan penyaringan dua tidak ada perbedaan. Penelitian ini merupakan penelitian eksperimen dengan menggunakan desain pre and post only design.

Hasil penelitian berdasarkan uji laboratorium menunjukkan bahwa terdapat penurunan jumlah bakteri coliform sesudah dilakukan penyaringan dengan menggunakan cartridge berukuran 0,5 mikron dan 0,1 mikron.

Penyaringan ini dapat dimanfaatkan untuk menurunkan jumlah bakteri di dalam air dan apabila ditambah alat dengan lengkap dapat digunakan untuk pengolahan air.
\end{abstract}

Kata kunci : air, bakteri coliform, pengolahan air minum

Air merupakan salah satu sumber daya alam yang memiliki fungsi sangat penting bagi kehidupan dan perikehidupan manusia. Air juga merupakan komponen lingkungan hidup manusia dan mahluk hidup lainnya. Akhir-akhir ini susah mendapatkan air bersih, air karena adanya pencemaran air yang disebabkan oleh limbah industri, rumah tangga dan limbah pertanian. Akibatnya air bersih menjadi barang yang sangat langka. (Alamsyah, 2007). pada era globalisasi ini banyak sekali masalah-masalah yang disebabkan pencemaran air dan kualitas air minum kurang baik, jarang sekali air yang kita minum sehari-hari mempunyai kulaitas yang baik, bahkan banyak orang yang menggunakan air minum dari air galon yang sumber airnya berasal dari pegunungan yang melalui proses RO (Reserve Osmosis) tetapi masih banyak yang mengandung bakteri coli, yang menyebabkan berbagai penyakit didalam tubuh kita.

Data kesehatan kota bengkulu tahun 2008, menunjukkan KK sebanyak 67,185 $\mathrm{KK}$, ketersediaan akses air bersih yang 
diperiksa sebanyak 34,925\% KK, sarana air bersih yang digunakan masyarakat yaitu sumur gali sebanyak $58,14 \%$, pada tahun 2009 jumlah KK sebanyak 61,793 KK, akses air bersih yang diperiksa sebanyak $26,085 \%$ yang dari data tersebut ada penurunan ketersediaan sarana air bersih yang diperiksa. Dari hasil pemeriksaan bakteriologis pada sumur gali di jalan Gandaria 09, Panorama, Kelurahan Gading Cempaka positif mengandung coliform sebesar 50/100 ml air.

Berdasarkan uraian tersebut maka dilakukan penelitian untuk membuat pengelolaan air minum sederhana untuk rumah tangga dengan menggunakan alat-alat tersebut seperti, katrid filter yang berukuran 0,1 dan 0,5 karbon blok, karbon granular, pompa stenlis, sehingga bisa dijadikan alat untuk penyaringan air minum sederhana untuk rumah tangga.

Air merupakan elemen yang sangat pentingdalam kehidupan manusia, karena banyak manfaat yang diberikan air untuk semua mahluk hidup. Air merupakan satusatunya zat secara alami terdapat di-permukaan bumi, air merupakan elemen yang sanygat penting bagi kehidupan ma-nusia, hewan, dan tumbuhan. Pada tubuh manusia air merupakan bagian terbesar, dimana hampir semua reaksi pada tubuh manusia memerlukan cairan.

\section{BAHAN DAN CARA KERJA}

Penelitian ini merupakan penelitian Analitik dengan pendekatan eksperimen dengan menggunakan desain "Pre Post Test Only Design”. (Notoatmodjo, 2010)

\section{HASIL}

Rerata jumlah bakteriologis air yang sudah dilakukan penyaringan satu dan penyaringan dua dengan post satu dan post dua, terlihat pada tabel di bawah ini :
Tabel 1. Hasil Rerata Penurunan Pemeriksaan Jumlah Bakteri Pada Penyaringan I Dan Penyaringan II, Post I dan Post II :

\begin{tabular}{llll}
\hline & \multicolumn{2}{c}{ Jumlah Bakteri } & $\begin{array}{c}\text { Rerata } \\
\text { Jumlah } \\
\text { Penurunan }\end{array}$ \\
\hline Penyaringan I & Pre I & Post I & \\
& 518,50 & 7,75 & 510,75 \\
Penyaringan II & Pre II & Post II & \\
& 518,50 & 6,00 & 512,5 \\
\hline
\end{tabular}

Penurunan jumlah bakteri pada penyaringan satu dan penyaringan dua. Pengaruh jumlah penurunan jumlah bakteri pada penyaringan dua dapat diketahui dengan uji t-test. Hasil uji statistik dapt dilihat pada tabel 2

Tabel.2 Uji Beda Penyaringan I dan Penyaringan II

\begin{tabular}{lccc} 
& $\mathrm{t}$ & $\mathrm{CL}$ 95\% & $\mathrm{P}$ value \\
\hline Penyaringan - & 1,219 & $-2,820-$ & 0,310 \\
penyaringan II & & 6,320 & \\
\hline
\end{tabular}

Uji beda pada penyaringan I dan penyaringan II dengan nilai $t=1,219$. Pada penyaringan I dan penyaringan II tidak ada perbedaan yang signifikan dengan nilai pvalue 0,310. Sehingga tidak ada perbedaan yang bermakna antara penyaringan I dan penyaringan II.

Rerata penyaringan I adalah $7,75 \mathrm{mg} / \mathrm{l}$ dengan standar deviasi 2,872 mg/l. Pada penyaringan II didapat Rerata adalah 0,06 $\mathrm{mg} / \mathrm{l}$ dengan standar deviasi $2,449 \mathrm{mg} / \mathrm{l}$. Terlihat nilai mean perbedaan antara penyaringan I dan penyaringan II adalah 1,75 $\mathrm{mg} / \mathrm{l}$ dengan standar deviasi $2,872 \mathrm{mg} / \mathrm{l}$. Hasil uji statistik didapat nilai 0,310, maka dapat disimpulkan tidak ada perbedaan yang signifikan antara penyaringan I dan penyaringan II.

\section{PEMBAHASAN}

Berdasarkan hasil analisis secara statistik diketahui bahwa rerata penurunan jumlah bakteri yang banyak mengalami penurunan yaitu pada penyaringan II, dengan jumlah bakteri yang tersaring $512,5 \mathrm{mg} / \mathrm{l}$ dalam air. Terlihat pada tabel 4.1. jumlah bakteri yang tersaring pada penyaringan II lebih banyak. 
Setelah diuji menggunakan uji t-test, penyaringan I dan penyaringan II tidak ada perbedaan dengan nilai $\mathrm{p}$ value 0,310 , dapat dilihat dari tabel 4.2, dari hasil penurunan jumlah bakteri coliform sebelum dan sesudah penyaringan mengalami penurunan jumlah bakteri coliform yang sangat signifikan dengan nilai 512,5.

Menurut teori biologi interaktif, bakteri Escherichia coli merupakan bakteri gram negatif yang tahan hidup dalam media yang kekurangan zat gizi. Susunan dinding sel bakteri gram negatif memiliki struktur dinding sel yang lebih kompleks dari pada sel bakteri gram positif.

Menurut Oman, 2008. Total E coli terdiri dari E. Coli yang berasal dari tinja atau coli fecal (baru tercemar tinja), lalu bakteri-bakteri lain selain E. Coli (disebut coliform) seperti Klebsiella sp.

Medium EMBA merupakan medium deferensial, yaitu medium yang dapt memisahkan antara koloni bakteri yang berbeda dan digunakan sebagai media isolasi dan identifikasi.

Hasil penelitian ini secara keseluruhan dapat dikatakan bahwa penyaaringan air dengan menggunakan katrid berukuran 0,5 mikron dan katrid 0,1 mikron belum efektif. Namun apabila dibandingkan dengan penelitian terdahulu yang dilakukan muhammad Rudi (2011) hasilnya sangat berbeda meskipun sampel yang digunakan sama. Perbedaan hasil penelitian ini menunjukkan bahwa penelitian terdahulu belum tentu hasilnya sama seperti penelitian sekarang. Keadaan ini dipengaruhi oleh adanya alat yang kurang lengkap, karena hanya memakai katrid dua buah yang berukuran 0,5 mikron dan 0,1 mikron dan menggunakan tabung arang aktif yang berukuran $25 \mathrm{~cm}$ dan karbon granular yang berukuran $25 \mathrm{~cm}$ sehingga bakteri coliform yang ada didalam air tidak tersaring secara efektif. Sedangkan ukuran bakteri yang terkecil yaitu $0,001 \mathrm{~mm}$ (mili mikron)

\section{DAFTAR RUJUKAN}

Adam, 1992. Dasar-Dasar Mikrobiologi Dan Parasitologi. Jakarta: EGC. sehingga dengan menggunakan dua buah katrid belum dapt menjadilkan air yang disaring langsung dapat diminum, sedangkan untuk air bersih sudah memenuhi syarat. Menurut permenkes 492 tahun 2010 standar bakteri dalam air minum adalah nol.

Adapun hambatan dalam penelitian ini, pada saat penanaman bakteri bertepatan pada hari libur sehingga waktu penanaman terlambat dan pada waktu pengambilan sampel air baku mengalami hambatan karena tali yang digunakan untuk mengambil sampel kurang panjang, dalam pembacaan hasil di tabel MPN kurang mengerti dan pembuatan media kurang memahami cara perhitungannya.

\section{KESIMPULAN}

Berdasarkan penelitian dan analisis data yang telah dilaksanakan pada penelitian yang berjudul Efektifitas Pengolahan Air Minum Untuk Rumah Tangga dapat diambil beberapa kesimpulan, yaitu tidak ada perbedaan yang bermakna sehingga tidak ada pengaruh antara penyaringan I dan penyaringan II, hasil uji laboratorium didapatkan hasil Rerata penyaringan I menggunakan katrid 0,5 mikron adalah $7,75 \mathrm{mg} / \mathrm{l}$ dan penyaringan II menggunakan katrid 0,1 mikron 6,00 $\mathrm{mg} / \mathrm{l}$. Setelah diuji dengan statistik tidak ada pengaruh penyaringan I penyaringan II dengan nilai $0,310>0,05$.

Untuk penelitian selanjutnya sebaiknya jika ingin menggunakan penyaringan air minum secara sederhana yang perlu ditambah adalah jumlah catridge sebanyak 6 buah kemudian menambah ukuran menjadi lebih panjang sehingga bakteri yang tersaring dapat tersaring secara efektif pada penyaringan ini perlu dilengkapi menggunakan ultraviolet dan ozon.

Alamsyah, 2007. Teknologi Pengolahan Air Minum. Yogyakarta: Erlangga. 
Anonim, 2001. Biologi Kehidupan. Jakarta: Grafindo Media Pratama.

Herlambang, Arie. 2010. Teknologi Penyediaan Air Minum Untuk Keadaan Tanggap Darurat. Journal Volume 6, No 12010.

Ariyani, 2011.2 Escericiacoli. Http://Nillaprianinaim.Wordpress.Com/2011/ 06/25/Escherichia-Coli/

Azwan, 1996. Teknologi Pengolahan Air Minum. Jakarta: Rineka Cipta.

Bitton, 1994. Biologi Interaktif. Jakarta: Ganeca Exact.

Chandra, 2007. Pengantar Kesehatan Lingkungan. Jakarta: EGC.

Fardias, 1989. Mikrobiologi Pangan (Pusat Antara Universiti). Bogor: Institut Pertanian Bogor.

Ganeti, 2005. Pengolahan Air Minum Sumur Gali Untuk Rumah Tangga Secara Aerasi Dan Desenfeksi. Juornal Volume 6. 2005.

Joko,T. 2010. Unit Air Baku Dalm Sistem Penyediaan Air Minum. Yogyakarta: Graha Ilmu.

Karman, 2008. Biologi. Jakarta: PT Garafind.

Karsidi, 1991. Teknologi Pengolahan Air Minum. Jakarta: Rineka Cipta.

Kementeriaan Perindustriaan Dan Perdagangan, 2005. Buku Pedoman Operasional Depot Air Minum. Jakarta:
Kumalasari, 2011. Teknik Praktis Mengolah Air Kotor Menjadi Air Bersih Hingga Layak Minum. Jakarta:

Mukono, 2008. Prinsip Dasar Kesehatan Lingkungan. Surabaya: Airlangga.

Notoadmodjo, 2010. Metodologi Penelitian Kesehatan. Jakarta: Rineka Cipta.

Permenkes 492, 2010. Persyaratan Kualitas Air Minum.

Pitojo, 2003. Mikrobiologi Air. Bandung:

Pitojo, S. 2003. Deteksi Pencemaran Air Minum. Semarang: Aneka Ilmu.

Purwanto, 1985. Ekologi Lingkungan Pencemaran. Semarang: Satyawacana.

Rudi, M. 2010. Uji Kualitas Produk Air Minum Pada Depot Air Minum Isi Ulang Terhadap Kandungan Mikrobiologi. Journal. Volume 2. 2010.

Saiful, 2001. Pengantar Mikrobiologi Umum. Bandung:

Salim, 1986. Teknologi Pengelolaan Air Minum. Yogyakarta:

Slamet, Js. 2009. Kesehatan Lingkungan. Yogyakarta: Gadjah Mada University

Susanto, 2006. Basic Data Analisis For Health Research. Jakarta: UI.

Sutrisno,C. Totok, 2000. Teknologi Penyediaan Air Bersih. Jakarta: Rinek Cipta.

Waluyo, Iud, 2008. Teknik Dan Metode Dasar Dalam

Mikrobiologi 